\title{
Kurumsal Yönetim İlkelerinin Türkiye Muhasebe Standartlari (TMS) ve Türkiye Finansal Raporlama Standartlari (TFRS) İçindeki Yeri
}

\author{
Zülkif YALÇIN ${ }^{1}$, Meltem YOLUK ${ }^{2}$
}

Özet

Son yıllarda artan rekabet ortamı ve yaşanan uluslararası finansal krizler kurumsal yönetim ilkelerinin işletmeler için önemini arttırmıştır. Gerek uluslararası alanda gerek Türkiye'de kurumsal yönetim ilkelerin ișletme yönetimlerinde önemli değişiklik yarattığı anlaşılmıştır. İlkeler bağlamında işletmeler piyasaya güven vermek için kendi iç bünyesinde de bazı değişikliklere gitmesi gerektiği amacıyla belli başlı arayışlara gitmişlerdir. Kurumsal yönetim ilkelerini benimsememiş işletmelerin piyasadaki yetersizliği ve başarılı olamamaları olasılığı mevcuttur. Kurumsal yönetim ilkeleri aynı doğrultuda olup amaçları birdir. İşletmeler ve ülkeler kültürel olarak farklllık gösterse de bu ilkelerin oluşumundaki amaç değișmez. Bu yüzden uluslararası alanda bazı standartlar oluşturulmuş ve oluşturulan bu standartlara uygun bazı ilkeler düzenlenmiştir. Ülkemizde de bu standartlara paralel olarak çalışmalar yapılmış ve ortaya çıkan ilkelerin uygulanması yönünde çalışmalar yapılmıştır. Kurumsal Yönetim İlkeleri; eşitlik, şeffaflık, hesap verilebilirlik ve sorumluluk temel ilkelerinden oluşmaktadır. Bu çalışmada kurumsal yönetim ilkelerinin TMS ve TFRS içindeki yeri ve önemi araştırılmış olup ilgili standartlar tek tek incelenmiş kurumsal yönetim ilkeleri ile ilişkisi ortaya çıkarılmaya çalışılmıştır.

Anahtar kelimeler: TMS, TFRS, Kurumsal Yönetim İlkeleri.

Jel Kodu: C01, C23, K12

\section{Corporate Governance Principles in Turkey Accounting Standards and Turkey Financial Reporting Standards}

\section{Abstract}

In recent years, increasing competition and international financial crises have increased the importance of corporate governance principles for enterprises Both international area and in Turkey is in even more increased emphasis on corporate governance has been found to have a significant impact on business management of these principles.The principles of corporate governance have been developed in order to make the enterprises become more reliable, strong institutions and to recover the lost trust. Inadequacies of firms that have not adopted the principles of corporate governance and their failure to succeed have emerged in the studies. Although the principles of corporate governance vary from country to country and from institution to institution, almost all of them are in the same direction. Therefore, some standards have been formed in the international arena and our country has established principles that comply with these standards, which are briefly; equality, transparency, accountability and responsibility. In this study, the place and importance of corporate governance principles in TMS and TFRS has been investigated and the related standards are tried to be revealed by interpreting the relationship between the individual and the corporate governance principles.

Keywords: Turkish Accounting Standards, Turkish Financial and Report Standards, Corporate Governance Principles. Jel Codes: C01, C23, K12

\section{GiRis}

Günümüzde dünyada ekonomik ve sosyal alanda hızlı değişimler yaşanmaktadır. $\mathrm{Bu}$ gelişmeler ışığında işletmeler giderek küreselleşen dünyada ve artan rekabet ortamında işlerini yürütmek zorundadır. Böyle bir ortamda işletmelerin ayakta durabilmesi için iyi muhasebe standartlarının oluşturulması ve bunların işletme içinde uygulanması gerekmektedir. Ayrıca işletmelerin ticari anlamda sınırların kalktığı birçok ülkeden birçok insan ve şirketlerle ticaret yapmaları için iyi bir yönetime ihtiyaç duyduğu açıktır.

Dünyada ve ülkemizde bazı işletmelerin piyasa güvenini sarsıcı durumlarla hareket ettikleri ve bu hareket sonucunda ekonomik ve sosyal alanda uluslararası bazı sorunlarla

\footnotetext{
1 Dr.Öğr. Üyesi, Munzur Üniversitesi, İktisadi ve İdari Bilimler Fakültesi, Merkez / TUNCELİ,

EMAIL: zulkifyalcin@gmail.com ORCID:0000-0002-4118-8316

${ }^{2}$ Yüksek Lisans Öğrencisi, Munzur Üniversitesi, Sosyal Bilimler Enstitüsü, Merkez / TUNCELİ,

EMAIL: meltemyoluk@gmail.com ORCID: 0000-0003-3576-5655
} 
karșılașıldığını, yașanan ekonomik krizlerle birlikte finansal bilgi hazırlayıcılarının güvenirliklerini sarsıldığı görülmektedir (Atabey ve Yllmaz, 2005 aktaran Dinç ve Abdioğlu, 2009). Bu durum kurumsal yönetimi bir bilgi sistemi ve haberleşme yaklaşımı olarak ön plana çıkarmaktadır. (Dinç ve Abdioğlu, 2009). Bu sorunlar neticesinde ülkemizde ve dünyada bazı çalışmalar yapılmış, bu çalışmalar sonucunda da kurumsal yönetim ilkeleri ve Türkiye Muhasebe Standartları ve Türkiye Finansal Raporlama Standartları olușturulmuştur. $\mathrm{Bu}$ ilke ve standartlarla birlikte işletmeler piyasaya, yatırımcılara ve diğer bilgi kullanıcılarına daha güvenilir raporlamalar yapmaya başlamışlardır.

$\mathrm{Bu}$ araştırmanın amacı işletmelerin yönetilmesinde kullanılan TMS ve TFRS standartlarının kurumsal yönetim ilkeleriyle uyumunun belirlenmesi ve aralarındaki ilişkinin saptanmasıdır. Çalışmanın uygulama bölümünde kurumsal yönetim ilkelerinin tanımı ve tarihçesine değinilecek, TMS ve TFRS içindeki kurumsal yönetim ilkelerinin yeri hakkında bilgi verilecek ve en sonunda kurumsal yönetim ilkelerinin bu standartlarla karşılaştırılması yapılarak bir tabloyla ortaya konacaktır.

\section{KURUMSAL YÖNETIM KAVRAMI VE TARİHSEL GELISŞIMI}

Günümüzde hem ülkemizde hem de dünyada işletmeler bağlamında yaşanan hızlı değişimler, yönetimsel anlamda ortaya çıkan yeni fikir ve düşünceler, muhasebe kayıtlarında ve raporlanmalarında ortaya çıkan gelişmeler işletme yönetiminde yeni yaklaşımların ortaya çlkmasına sebep olmuştur. Bunun sonucunda da kurumsal yönetim ilkeleri ortaya çıkmıştır. (Akyüz, Görmüş ve Bektaş, 2008 aktaran Dinç ve Abdioğlu, 2009).

Ulusal ekonomilerin büyümesi, uluslararası ekonomik ilişkilerin gelişmesi, uluslararası sermaye akışkanlığın artması, şirket hissedarlarının işletme yönetimindeki etkinliklerinin azalması, şirket yönetim kurulları ve kurul yöneticilerinin verdiği kararların öneminin artması gibi etkenler, kurumsal yönetim ilkelerinin doğuşunda etkili olmuştur (Koçel, 2003).

Kurumsal yönetim ilkelerinin ortaya çıkmasına sebep olan en önemli etkenler ortaklık yönetimlerindeki başarısızlıklar, suiistimaller, gelişen piyasalarda yaşanan finansal krizler olarak önümüze çlkmaktadır (Clark ve Demirağ, 2002). Bunun yanında özel sektörün artan rolü, ülkelerin ekonomik olarak birbirine olan bağlılıklarının artması ve ortakların içinde bulundukları yeni rekabet şartlarından dolayı işletmelerin bilgi sistemlerine olan ihtiyacı artmıştır (Şehirli, 1999).

Mayıs 1999 yılında Ekonomik İşbirliği ve Kalkınma Örgütü (OECD) tarafından "OECD Kurumsal Yönetim İlkeleri (KYI)" belirlenmiştir. $\mathrm{Bu}$ örgütün bu ilkeleri belirlenmesinde temel sebepler, yukarıda belirtilen sorunların sonucunda, yeni bir kurumsal yönetim biçiminin belirlenmesindeki ihtiyaçtır. Bu ihtiyaçtan dolayıdır ki bu örgüt "kurumsal yönetim ilkelerini" ilk defa bu toplantıda dile getirmiş ve uygulanması için harekete geçmiştir. Tüm bu gerekçeler dünyada uluslararası kurumlarda tartışılmaya başlanmış ve kurumsal yönetim biçimi bulunmaya çalışılmıştır. (Karğın ve diğerleri, 2015)

ABD'de ortaya çıkan ve finansal krizlere yol açan Enron-Worldcom gibi şirketlere ait skandallar sonucunda tüm dünyada finansal raporların güvenilirliği ve șeffaflığı tartıșılmaya başlanmıştır. Bu bağlamda finansal raporların kontrollerinin arttırılması denetim skandallarının ortadan kaldırılması için 2002 yılında Sarbones-Oxley (SOX) (Halka Açık Şirketler Muhasebe Reformu Ve Yatırımcıyı Koruma Yasası) yasaları düzenlenmiștir. $\mathrm{Bu}$ yasalarla esas hedeflenmek istenen yönetim ilkelerinin uygulanmasında ve bu uygulamalar sonucunda ortaya çlkan denetim raporlarının güvenirliliğini ve şeffaflığını artırmaktır. (www.pwc.com.tr).

Ülkemizde de Sermaye Piyasası Kurulu (SPK) tarafindan bu yasalara paralel olarak düzenlemeler yapılmış ve ilk olarak 2003 yılında ve daha sonrada 2005 ve 2014 yılında 
bu yasalar güncellenmiștir. Bununla birlikte SPK, şirketlerin 2004 yılından itibaren faaliyet raporlarında ve internet sitelerinde kurumsal yönetim ilkelerini uyguladıklarına dair bilgilere yer vermesi gerektiğini belirtmiş ve işletme bünyelerinde "Kurumsal Yönetim Uyum Raporu'na (KYUR)" yer vermeleri gerektiğine karar vermiștir (SPK, 10 / 12 / 2004 tarih ve 48 /1588 sayılı karar).

Kurumsal yönetim TÜSİAD’ın 2002 yllında yayınlamış olduğu kurumsal yönetim ilkelerinin uygulanışına yönelik yayında şöyle tanımlanmıștır; "işletmede hedef ve kuruluş gayesine varabilmek için oluşturulan yönetim faaliyetlerinin kurallar ve prensipler çerçevesinde düzenlenmesi ve yürütülmesidir. Diğer bir ifade ile bir işletmenin beşeri ve finansal sermayeye ulaşmasına, bu konuda yapılacak faaliyetleri yerine getirmesine ve ekonomiye katkı sağlamasına yardımcı olacak her türlü anayasa, kanun, yönetmelik, kural, prensip ve uygulamalarl anlatır" (TÜSİAD, 2002). Ülzen ve Mirze, (2004) ise Kurumsal yönetim kavramını; "işletmenin stratejik yönetimi ile sorumlu üst yönetimin, bu görevlerini ve sorumluluklarını yerine getirirken, işletme üzerinde kendilerini belirli nedenlerle "hak sahibi" gören pay sahipleri, çalışanları, tedarikçi, müșteri ve diğer toplumsal kavramlarla olan ilişikler bütünü" olarak tanımlamaktadır (Ülzen ve Mirze, 2004). Aysan (2007) da kavramı şöyle açıklamıştır; "Kurumsal yönetim sistemi işletmelerde, bir yandan ekonomik ve sosyal hedefler arasinda, öte yandan işletme topluluğunun hedefleri ile çalışanın hedefleri arasında dengenin kurulmasını sağlamak amacıyla alınabilecek önlemlerden ve bu önlemlerin, kullanılmasının zorunlu kılındığı, insan kaynakları, cihazlar, yöntem ve prosedürlerden oluşur" (Aysan, 2007). Bu haliyle kurumsal yönetim ilkelerinin tanımından da yola çıkarak kurumsal yönetim ilkelerinin temel taşları; yönetim faaliyetlerinin kurallar ve prensipler çerçevesinde düzenlenmesi gerektiği, beşeri ve finansal sermayeye ulaşmada ekonomik katkıyı artırmaya yardımcı olacak kanun-yönetmelikkuralların belirlenmesi gerektiği ve bu ilkeler çerçevesinde işletmenin paydaşları ile olan ilişkilerini şeffaflaştırması ve bütünleştirmesidir.

\section{KURUMSAL YÖNETIM ILKELERİ}

Kurumsal yönetim ilkeleri 13.01.2011 tarihinde kabul edilen 6102 sayll yeni Türk Ticaret Kanunu ile yürürlüğe girmiştir. Kabul edilen bu kanunla yürürlüğe giren kurumsal yönetim ilkelerinin temel hedefleri; 1) tüm çıkar sahiplerinin menfaatlerinin en üst düzeyde korunmasl, 2) şirket ve kurumlarımızın rekabet gücünün arttırılmasl, 3) iyi ve etkin bir yönetim kurulunun oluşmasının sağlanması, 4) yönetim kurullarının kararları en doğru ve uygun zamanda alabilme yeteneğinin geliştirilmesidir (Yılmaz ve Kaya, 2014).

6102 sayılı Türk Ticaret Kanunda kurumsal yönetim anlayıșı dört temel ilke etrafında şekillendirilmiştir. Bunlar; adillik, seffaflık, hesap verilebilirlik ve sorumluluk olarak siralanır.

Adillik (Fairness) veya Eşitlik İlkesi: Bu ilke; işletmelerde yönetimin paydaşlar ile işletme faaliyetlerine ilişkin tüm bilgileri ve icraatları eşit ve adil bir şekilde paylaşmasını ifade eder. $\mathrm{Bu}$ durum işletmenin pay ve menfaat sahiplerine eșit ve adil davranılması muhtemel çatışmaları da engellemiş olur (SPK, 2005).

Şeffaflık (Transparency): Şeffalık ilkesi yasal çerçeve içerisinde işletmenin faaliyet ve icraatlarına yönelik tüm bilgileri kamuya ilan edilmesini ifade eder. Yani işletmenin finansal ve finansal olmayan bilgilerini eksiksiz ve doğru bir şekilde anlaşılmasında ve yorumlanmasında herkese hitap edecek bir biçimde ilan edilmesidir. (SPK, 2005).

Hesap Verebilirlik (Accountability): $\mathrm{Bu}$ ilkede yine yukarıdaki iki ilkeye uygun olarak işletmenin faaliyetlerini ve icraatlarını yürüten yürütme kurulunun yani yönetimin bu icraat ve faaliyetlerine ilişkin işletme paydaşlarına hesap verebilmesidir. (SPK, 2005).

Sorumluluk (Responsibility): Bu ilkede genel kurula yönelik düzenlenmiş bir ilkedir. Yönetim kurulunun almış aldığı kararlar ve bu 
kararlar neticesinde yapmış olduğu faaliyetler ve icraatlar neticesinde ortaya çlkan performansların ve sonuçların şirket ana sözleşmesinde ve diğer ilgili kanun ve yönetmelik ile kurallara uygun olduğuna ve bunun kontrol edilebileceğini ifade etmektedir (SPK, 2005).

$\mathrm{Bu}$ dört ilke incelendiğinde aslında yönetimin işletmenin tüm paydaşlarına yönelik sahip olduğu sorumluluğu hatırlatmakta ve yapmış olduğu faaliyet ve icraatlarında toplumun tüm kesimine hitap edip etkilediğini söylemektedir. $\mathrm{Bu}$ bağlamda bu konularda yönetimin daha dikkatli, doğru ve hesap verebilir bir şekilde sorumluluk sahibi olması gerektiğini belirtilmiştir (Millstein, 1998). Aslında bu ilkeler yönetimin topluma karşı sorumluluğunu açıklarken aynı zamanda yönetimin doğru hedef ve kararlar alması gerektiğini belirtmekte ve bu uygulamaları kanunlar çerçevesinde güvence altına alınması gerektiğini belirtmektedir

\section{ARAŞTIRMA HAKKINDA BİLGİLER}

Kurumsal Yönetim İlkelerinin TMS ve TFRS içindeki yeri hakkında yapılan araştırma literatür taraması yapılarak konu hakkında yeteri kadar veri taranmış ve 30 adet Türkiye Muhasebe Standartları ve 15 adet Türkiye Finansal Raporlama Standartları içindeki ilișkisi analiz edilmiștir. Analiz edilirken tablo oluşturularak karşılaştırma yöntemiyle sonuçlar elde edilerek sınıflandırılmıştır.

Araştırmanın amacl işletmelerin yönetilmesinde kullanılan TMS ve TFRS standartlarının kurumsal yönetim ilkeleriyle uyumunun belirlenmesi ve aralarındaki ilişkinin saptanarak karşılaştırmasının yapılmasıdır.

Araștırma yöntemi ise, her bir standardın kurumsal yönetim ilkeleriyle ilişkisinin tek tek incelenerek

tablo

yöntemiyle karşılaştırılmasının yapılmasıdır.

\section{KURUMSAL YÖNETIM İLKELERİNIN TÜRKIYE MUHASEBE STANDARTLARI İÇINDEKİ YERİ}

$\mathrm{Bu}$ başlık altında kurumsal yönetim ilkelerinin TMS içindeki yeri analiz edilecek olup her bir standart ayrı ayrı incelenecektir.

\subsection{TMS 1: Finansal Tabloların Sunuluşu}

TMS 1 Finansal Tabloların Sunuluşu hakkında standartlar olup içinde toplam 127 maddelik standart yer almaktadır. TMS1 incelendiğinde şeffaflık ilkesiyle yakından ilgili olduğu anlaşılmaktadır. Çünkü şeffaflık ilkesi; şirket ile ilgili finansal ve finansal olmayan bilgilerin gerçeğe uygun, açık, anlaşılır olarak kamuya ilan edilmesini ifade etmekte ve TMS 1 içindeki maddelerde bu tanımla yakından ilişkisi olduğu görülmektedir. Madde 13, 15, 21 b, 34, 106, 109,119 ve 124 'te "gerçeğe uygun yansitılması gerektiği' ifadesi kullanılmıştır ${ }^{1}$. $\mathrm{Bu}$ madde üzerinden açıklamak gerekirse, Finansal tabloların performansının gerçeğe uygun sunuluşu aslında șeffaflık ilkesinin dürüstlük ve güvenilirliğiyle ilgilidir.

Ayrıca finansal tabloların hazırlanışı ve sunuluşu şirketin yönetim kurulunun sorumluluğunda olduğu için bu standardın aynı zamanda kurumsal yönetim ilklerinden hesap verilebilirlik ilkesiyle de bağlantısı belirlenmiş olup yönetim kurulunun şirket paydaşlarına karşı hesap verme zorunluluğu bulunmaktadır.

\subsection{TMS 1: Finansal Tabloların Sunuluşu (Değişiklik):}

TMS 1 de 16/1/2005 tarihinde yapılan madde 124'teki değişiklikte eklenen ifade de seffaflık ilkesiyle uyumunu ayrıca yansitmaktadır.

kriterlerine sadık kalınarak, sunulması demektir. TMS' nin gerektiğinde ek açıklamalarla birlikte uygulanmasının, gerçeğe uygun sunuşu sağlamış finansal tablolar yaratacağı, varsayılır"(TMS 1, Madde 13).
1 "Finansal tablolar işletmenin finansal durumunu, finansal performansını ve nakit akışlarını gerçeğe uygun olarak sunar. Gerçeğe uygun sunuş, işlemlerin sonuçlarının, diğer olayların ve koşulların çerçevede belirtilen varlıklar, yabancı kaynaklar, gelir ve giderlerin tanımlarına ve tahakkuk 


\subsection{TMS 2: Stoklar}

TMS 2 Stoklar hakkındaki standartlar olup toplamda 40 maddeden oluşmaktadır. Stoklarla ilgili bu standartlar incelendiğinde kurumsal yönetim ilkelerinden herhangi biriyle doğrudan ilişkisi olmadığı görülmüştür. $\mathrm{Bu}$ standartlarda şirketin, şirketin yönetim kurulunun veya pay sahiplerinin menfaatiyle ilgili bilgilere yer verilmediğinden aralarında ilişki saptanamamıştır.

\subsection{TMS 7: Nakit Akış Tabloları:}

TMS 7 Nakit Akış Tabloları hakkındaki standartları yansitıp 53 maddeden oluşmaktadır. TMS 7 incelendiğinde bu maddelerin Seffaflık ilkesiyle ilişkisi olduğu görülmektedir. Zaten TMS 1'de finansal tabloların şeffaflıkla ilgisi olduğunu görmüștük. Nakit Akım Tabloları da bir Finansal Tablo olduğundan aynı kurumsal yönetim ilkesiyle ilişkisinin saptanması doğaldır. Örneğin Madde 4'te ${ }^{1}$ anlatılan "farklı muhasebe uygulamalarının elimine edilmesi" aslında kamuoyuna bu tablonun daha doğru ve güvenilir bir şekilde yansitılmasının gerektiğidir. Bundan dolayı bu cümleden de şeffaflık ilkesinin ağır bastığını anlamak mümkündür.

\subsection{TMS 8: Muhasebe Politikaları, Muhasebe Tahminlerinde Değişiklikler Ve Hatalar}

TMS 8 muhasebe politikaları, muhasebe tahminlerindeki değișikler ve hatalarla ilgili 53 maddelik standartlardan oluşmaktadır. TMS 8 madde 1 incelendiğinde ${ }^{2}$; kullanılan ifade kurumsal yönetim ilkelerinden şeffaflıkla ilgili olduğunu göstermektedir.

\footnotetext{
1 "Nakit akışı bilgisi işletmenin nakit ve nakit benzeri yaratma yeteneğinin değerlendirilmesi ve kullanıcıların gelecekteki nakit akışlarını ölçmek ve başka işletmelerle karşılaştırmak için modeller geliştirmesini sağlar. Ayrıca İsletmeler arasındaki aynı işlem ve olaylar için farklı muhasebe uygulamalarının etkilerini elimine ederek farklı işletmelerin performans raporlamalarının karşılaştırılabilmelerine olanak verir."(TMS 7,Madde 4)

2 "Standart, işletmenin finansal tablolarının geçerlilik ve güvenilirliğini artırmayı ve işletmenin önceki dönemlerin
}

Ayrica bu standartlar hangi muhasebe politikasının seçilmesi gerektiğinden ve geçmiş dönemde yapılan muhasebe hatalarının nasıl düzeltilip doğru ve dürüst bir şekilde sunulması gerektiğinden bahsetmektedir. Bu da bilginin güvenilirliğinin sağlanmaya çalışıldığını göstermekte olup seffaflı ilkesiyle bağdaşmaktadır.

\subsection{TMS 10: Bilanço Tarihinden Sonraki Olaylar}

TMS 10 bilanço tarihinden sonraki olaylarla ilgili açıklanmış 23 maddeden oluşmaktadır. TMS 10 incelendiğinde madde $1^{\prime}$ de $^{3}$ kullanilan ifadelerde de yer almaktadır. Buradan anlașllacağı üzere TMS 10 ișletmeyle ilgili finansal bir tablonun içinde yer alması gereken olaylarla ilgili standartların kamuoyuyla nasıl paylaşılmasıyla ilgili hususları ele almıştır. $\mathrm{Bu}$ yüzden işletmeyle ilgili finansal bilginin toplumla paylaşılması seffaflık ilkesiyle ilgili olduğundan TMS 10 şeffaflık ilkesiyle ilgilidir diyebilmekteyiz.

\subsection{TMS 11: İnşaat Sözleşmeleri}

TMS 11 inşaat sözleșmeleriyle ilgili 46 maddelik standarttır. TMS 11 incelendiğinde, Bu Standart kapsamında yüklenici ișletmelerin finansal tablolarındaki inşaat sözleşmelerinin muhasebeleştirilmesinde uygulanır kapsamı yer almaktadır. bu standart kapsamında geçen inşaat sözleşmelerinin kapsam ve maddelerine bakıldığında kurumsal yönetim ilkelerinden herhangi biriyle doğrudan ilişkisine rastlanmamıștır.

\subsection{TMS 12: Gelir Vergileri}

TMS 12 Gelir Vergileriyle ilgili 88 maddelik standarttan oluşmaktadır. TMS 12

finansal tablolarıyla ve diğer işletmelerin finansal tablolarıyla karşılaştırılmasını sağlamayı amaçlamaktadır."(TMS 8, Madde 1)

3 "bu standardın amacı; bir işletmenin, bilanço tarihinden sonra ortaya çıkan olaylar nedeniyle finansal tablolarında hangi durumlarda düzeltme gerekeceğini, bilançonun yayımı için onayın verildiği tarih hakkında ve bilanço tarihinden sonraki olaylarla ilgili finansal tablolarda açıklanması gereken bilgileri belirlemektir"'(TMS 10, Madde 1) 
incelendiğinde bu standartta madde $81,87 \mathrm{~A}$, 87B, 87C de işletmeyle ilgili vergilerin kamuoyuna açıklanmasından bahsetmektedir. Bunlar kurumsal yönetim ilkelerinden seffaflıkla ilgili olup ayrıca bağlı ortaklıkların, iştiraklerin, işletme yönetimin tümünün vergiye tabi olmaları da eşitlik yani adillik ilkesiyle ilgilidir.

\subsection{TMS 14: Bölümlere Göre Raporlama}

TMS 14 bölümlere göre raporlama, 83 maddelik standarttan oluşmuştur. TMS 14 incelendiğinde bu standartların kurumsal yönetim ilkelerinden sorumluluk ilkesiyle uyumlu olduğu saptanmıştır. Bölümlere göre raporlama standartlarının kapsamına baktığımızda işletmenin daha doğru kararlar almasını sağlamak için olușturulmuștur. $\mathrm{Bu}$ yüzden madde $33^{\prime} \mathrm{te}^{1} \mathrm{ki}$ İfadeden de anlaşılacak üzere her bölümün işletme yönetim kuruluna ve icra başkanına bilgi raporlayan örgütsel birim olarak tanımlanması aslında işletme içinde bölümlerin yönetim kuruluna, yönetim kurulunun da işletmeye sorumluluğunu ifade etmektedir. Ayrica madde 80 ve $76^{2}$ da değiştirilen bilgilerin kamuoyu ile paylaşılmasından söz ettiği için şeffaflık ilkesiyle bağlantılıdır. Bundan dolayı seffaflık ilkesinin etkisi TMS 14'te görülmektedir.

\subsection{TMS 16: Maddi Duran Varlıklar}

TMS 16 maddi duran varlıklar ile ilgili 80 maddeden oluşan standartlardır. TMS 16 standardının amacı ve diğer maddeleri incelendiğinde kurumsal yönetim ilkelerinden herhangi biriyle bir bağlantısı bulunmamıștır.

\footnotetext{
1 "Bu Standart kapsamında, tüm işletmeler, faaliyet alanı ve coğrafi bölümlerini her bir birimin geçmiş performansının değerlendirilmesi ve bu birimlere gelecekte yapılacak kaynak dağıtımına yönelik olarak işletmenin yönetim kuruluna ve icra kurulu başkanına bilgi raporlayan örgütsel birimler olarak belirler."(TMS 14 madde33)

2 "Bölüm raporlamasına yönelik olarak benimsenen muhasebe politikalarında meydana gelen ve bölüm bilgileri üzerinde önemli bir etkisi olan değişiklikler kamuoyuna açıklanır"'(TMS14 madde 76)
}

\subsection{TMS 17: Kiralama İşlemleri}

TMS 17 kiralama işlemleriyle ilgili 70 maddeden oluşan standarttır. TMS 17 standartları incelenmiş olup kurumsal yönetim ilkeleri ile bağlantısı bulunamamıştır.

\subsection{TMS 18: Hasılat}

TMS 18 hasılatlar ile ilgili 36 maddelik standarttır. Madde 1'in kapsamından ve diğer maddelerinden de anlaşlacağı üzere TMS 18 standardının kurumsal yönetim ilkelerinden herhangi biriyle ilişkisi bulunmamaktadır.

\subsection{TMS 19: Çalışanlara Sağlanan Faydalar}

TMS 19 çalışanlara sağlanan faydalarla ilgili toplam 156 maddeden oluşan standarttır. TMS 19 'da madde 30b,c, 32, 32B, 34B, 46, 60, 104C, $120,120 \mathrm{~A}, 122,131,141,142,155 \mathrm{~b}$ incelendiğinde bilgilerin kamuyu ile paylaşımı söz konusu olup kurumsal yönetim ilkelerinden seffaflık ilkesi ile ilişkisi vardır.

Ayrıca madde $135^{\prime} \mathrm{te}^{3}$ incelendiğinde bu maddenin de aslında adillik ilkesinden bahsettiğini ve sonuçlarının da bu ilke ile bağdaştığını görebilmekteyiz.

\subsection{TMS 20: Devlet Teşviklerinin Muhasebeleştirilmesi ve Devlet Yardımlarının Açıklanması}

TMS 20 devlet teşviklerinin
muhasebeleştirilmesi ve devlet yardımlarının açıklanmasıyla ilgili 41 standarttan oluşmaktadır. TMS 20 incelendiğinde, madde $10^{\prime} \mathrm{da}^{4}$ ki ifade de kurumsal yönetim ilkelerinden hesap verebilirlik ilkesiyle ilişkili olduğu görülmektedir. Çünkü işletmenin feragat koşullarının yerine getirilmesi

\footnotetext{
3 "Bir işletme, kanundan, çalışanları veya temsilcileri ile yapmış olduğu sözleşme veya başka bir düzenlemeden, ya da işletmenin kendi uygulamaları, gelenek veya adil davranma isteğinden kaynaklanan zımni kabulden doğan bir yükümlülükten dolayı çalışanlarına bunların işlerine son vermesi durumunda kendilerine belirli bir ödeme yapmayı taahhüt etmiş olabilir"(TMS 19, Madde 135)

4 "Devletten temin edilen feragat edilebilir kredi, feragat koşullarının işletme tarafından yerine getirileceğine dair makul bir güvencenin oluşması durumunda devlet teşviki olarak kabul edilir" (TMS 20, Madde 10)
} 
hakkında güvence vermesi bu koșulların ileride yerine getirilip getirilmeyeceğine dair hesap verebilmesi anlamına gelmektedir.

\subsection{TMS 21 Kur Değişiminin Etkileri}

TMS 21 kur değişim etkileri ile ilgili 60 maddeden oluşan standarttır. TMS 21 incelendiğinde kur değişim etkileri standartlarında madde $52,53,54,55,56$ ve 57 değişimin kamuya açıklanmasından bahsettiği için kurumsal yönetim ilkelerinden seffaflıkla ilgisi olduğu anlaşılmaktadır. Örneğin; TMS 21, Madde $53^{1}$ standardı incelendiğinde değișimin kamuya sebepleriyle birlikte açılkanması gerektiği vurgulanmıştır.

\subsection{TMS 23: Borçlanma Maliyetleri}

TMS 23 borçlanma maliyetleriyle ilgili 30 maddeden oluşan standarttır. TMS 23, Madde 92 incelendiğinde, dipnotlarda açıklanması gerektiği ifadesi yer almaktadır. Buna göre finansal tablolarda muhasebe politikalarının açıklanması seffaflık ilkesiyle ilişkisi olduğunu göstermektedir. Çünkü bu finansal tablolar kamuoyu ile paylaşılmaktadır. Kamuoyunun anlayabileceği bir sunum gerçekleştirilmelidir.

\subsection{TMS 24: İlişkili Taraf Açıklamaları}

TMS 24 ilişkili taraf açıklamalarıyla ilgili 20 standarttan oluşmaktadır. TMS 24 incelendiğinde madde $12,13,15,16,17$ ve 21

\footnotetext{
1 "Finansal tablolarda kullanılan para biriminin geçerli para biriminden farklı olması durumunda, geçerli para biriminin ne olduğu ve neden farklı bir para birimi kullanıldığı gerekçesiyle birlikte açıklanır" (TMS 21, Madde 53)

2 "Borçlanma maliyetleri ile ilgili olarak uygulanan muhasebe politikaları finansal tablo dipnotlarında açıklanır"(TMS 23, Madde 9)

3 "Ana ortaklıklar ve bağlı ortaklıkları arasındaki ilişkiler, aralarında işlem olup olmadığına bakılmaksızın açıklanır. İsletme, ana ortaklığının ve eğer farklıysa nihai kontrol gücüne sahip tarafın adını açıklar. İşletmenin ne ana ortaklığının ne de nihai kontrol gücüne sahip tarafın kamuya açıklanmak üzere finansal tablo hazırlamıyor olması durumunda, kamuya açıklanmak üzere finansal tablo oluşturan ikincil ana ortaklığın adı açıklanır" ( TMS24, Madde 12)

4 "Cari ücretler esas alınarak tespit edilmiş taahhüt edilen emeklilik faydalarının aktüeryal bugünkü değeri, finansal
}

ilișkili taraflarla ilgili bilgilerin kamuoyuna açıklanmasından bahsetmedir. Örneğin; TMS 24 Madde 12 'ye $^{3}$ bakıldığında ana ortaklık ile bağlı ortaklıkların arasındaki ilișkilerin kamuya açıklanasından bahsetmektedir. Bu açıklama kurumsal yönetim ilkelerinden seffaflık ilkesi ile ilişkisi olduğu anlaşılmaktadır.

\subsection{TMS 26: Emeklilik Fayda Planlarında Muhasebeleştirme ve Raporlama}

TMS 26 emeklilik fayda planlarında muhasebeleştirme ve raporlama ilgili 36 maddelik standarttan oluşmaktadır. Madde 26 (TMS26, Madde 26) ${ }^{4}$ incelendiğinde; cari ücretlerin bugün ki değeri, öngörülen ücretler ve tahminleri, emeklilik faydalarının bugün ki değerlerinin kamuya açıklanması gerektiğini belirtmektedir. Yani finansal tablolarda açılklanması gereken bilgilerden bahsetmiştir ve bu durum kurumsal yönetim ilkelerinden seffaflıkla ilgilidir.

\subsection{TMS 27: Konsolide ve Bireysel Finansal Tablolar}

TMS 27 konsolide ve bireysel finansal tablolara ilişkin 42 standarttan oluşur. TMS 27 Madde $38^{5}$ konsolide finansal tablolarin kamuya açıklanması gerektiğini belirttiğinden bu standart kurumsal yönetim ilkelerinden seffaflıkla ilgili olduğu anlaşılmaktadır.

Ayrıca Madde $39^{\prime} \mathrm{da}^{6}$ bu tabloların tüm paydaşlarla paylaşılması gerektiği ve onların

tablo tarihleri itibariyle sahip olunan fayda yükümlülüklerini belirtmek amacıla plana ilişkin finansal tablolarda açıklanır. Öngörülen ücretler esas alınarak tespit edilmiş taahhüt edilen emeklilik faydalarının aktüeryal bugünkü değeri ise, genelde fonlamanın temelini teşkil eden işletmenin sürekliliği ilkesi çerçevesinde potansiyel yükümlülüğün boyutunu belirtmek amacıyla açıklanır" (TMS26, Madde 26)

5 "Bu Standart, hangi işletmelerin kamuya açıklanmak üzere bireysel finansal tablo hazırlaması gerektiğini belirlemez. Bir işletmenin TFRS'ye uygun bireysel finansal tablo hazırlaması durumunda, Paragraf 37 ve 39-42 hükümleri uygulanır. Işletme, paragraf 10'da belirtilen istisnalar kapsamına girmedikçe, 9 uncu paragrafta zorunlu tutulduğu üzere, kamuya açıklanmak üzere konsolide finansal tablo düzenlemeye devam eder" (TMS 27, Madde 38)

"Konsolide finansal tablolarda TMS 39'a uygun olarak muhasebeleştirilen bağlı ortaklıklar, müştereken kontrol 
ilgili mali tablolarında da benzer yöntemlerle muhasebeleştirilmesi gerektiği belirtildiği için adillik ilkesi ile ilişkisi bulunduğu varsayılabilinir. Çünkü bu madde tüm taraflar için aynı yöntemin kullanılmasından bahsetmektedir. Aynı zamanda yönetim finansal tablo hazırlamadan işletme sahiplerine karşı hesap verme zorunluluğu olduğundan hesap verilebilirlik ilkesiyle ilişkisi de bulunmaktadır.

\subsection{TMS 28: İştiraklerde Yatırım}

TMS 28 iştiraklerde yatırım ile ilgili 40 maddelik standarttan oluşur. TMS 28, Madde $13 \mathrm{c}-\mathrm{i}^{1}$ incelendiğinde oy kullanmanın işletmenin tüm tarafları için eşit olması ve oy hakkı olmayanlarında dahil itiraz sürecinin işleyişinde eşitlikten bahsettiğinden bu standardında kurumsal yönetim ilkelerinden adillik ilkesiyle ilgili olduğunu söyleyebiliriz.

Ayrıca TMS 28 13c-iv² maddesi mali tabloların uygun bir şekilde kamuoyunun bilgisine sunulması gerektiğini anlattığından seffaflık ilkesiyle ilișkilidir.

\subsection{TMS 29: Yüksek Enflasyonlu Ekonomilerde Finansal Raporlama}

TMS 29 yüksek enflasyonlu ekonomilerde finansal raporlama ile ilgili 40 maddelik standarttır. TMS 29 incelendiğinde kurumsal yönetim ilkelerinden herhangi biri ile ilişkisi bulunamamıştır.

edilen işletmeler ve iştirakler, yatırımcının bireysel finansal tablolarında da aynı yöntemle muhasebeleştirilir" (TMS 27, Madde 39)

1 "Yatırımcı, tamamına bir başka işletme tarafından sahip olunan bir bağlı ortaklık veya bir başka işletmenin kısmen sahip olduğu bir bağlı ortaklık ise ve bu işletmenin diğer koşullarda oy verme yetkisi olmayanlar da dahil olmak üzere, diğer sahiplerinin öz kaynak yöntemi uygulanmaması konusunda bilgilendirilmiş ve buna itiraz etmemiş olmaları" (TMS 28, Madde 13c-i)

2 "Yatırımcının nihai ya da ara düzeydeki ana ortaklığı konumundaki işletmenin, Türkiye Finansal Raporlama Standartlarina uygun konsolide finansal tablolar hazırlayarak kamuoyunun bilgisine sunması" (TMS 28, Madde 13c-iv)

3"iş ortaklığının ürün, gelir, gider veya faaliyet sonuçlarının ortak girişimciler arasında paylaşımı"( TMS 31, Madde 10d)

\subsection{TMS 31: İş Ortaklıklarındaki Paylar}

TMS 31 iş ortaklıklarındaki paylar ile ilgili 57 maddelik standarttan oluşur. TMS 31 Madde $10-\mathrm{d}^{3}$ incelendiğinde bu madde ilgili faaliyet sonuçlarının girişimciler arasında paylaşımından bahsettiği için kurumsal yönetim ilkelerinden adillik ilkesiyle ilişkisi saptanmıştır. Ayrıca TMS 31 Madde 194 maddesi ise bulduğumuz ilişkiyi destekleyen bir diğer maddedir.

\subsection{TMS 32: Finansal Araçlar: Sunum}

TMS 32 Finansal araçlar sunum ile ilgili 50 madde ve ekten oluşan standarttır. TMS 32 incelendiğinde madde $3,4 a, 34,39,40,47,50$ ve 96 finansal tablo bilgilerinin kamuoyuna açıklanmasından bahsetmektedir. Örneğin TMS 32 Madde 3'te';Bu maddenin TFRS 7'yi tamamlayıcı bir madde olduğunu ve sonuçların kamuoyuyla paylaşılması gerektiğin anlattığından kurumsal yönetim ilkelerinden seffaflık ilkesi ile ilişkisi bulunmaktadır.

\subsection{TMS 33: Hisse Başına Kazanç}

TMS 33 hisse başına kazanç 73 madde ve ekten oluşan standarttır. TMS 33 incelendiğinde madde 3, 64, 70, 72 ve 73 hisse başına kazanç ile ilgili bilgilerin kamuoyuna açıklanmasından bahsetmektedir. Örneğin; TMS 33, Madde $3^{6}$ ifadesinde ilgili tutarların yine bu standartlara göre hazırlanıp kamuoyuna sunulması gerektiğini anlattığından bu maddenin de

\footnotetext{
4 "Bu iş ortaklıkları; bir şirket, ortaklık, başka bir işletme veya ortak girişimcilerden ayrı bir finansal yapı kurulmasını gerektirmez. Her ortak girişimci, müştereken kontrol edilen varlıktaki payları vasıtasıyla gelecekteki ekonomik yararlardaki payları üzerinde kontrole sahiptir" (TMS 31, Madde 19)

5 "Bu Standartta yer alan ilkeler, "TMS 39 Finansal Araçlar: Muhasebeleştirme ve Ölçme" Standardında yer alan finansal varlık ve borçların muhasebeleştirilme ve ölçümüne ilişkin ilkeler ile bunlara ilişkin bilginin kamuoyuna açıklanmasına yönelik olarak "TFRS 7 Finansal Araçlar: Açıklamalar" Standardında yer alan ilkeleri tamamlar" (TMS 32, Madde 3)

6 "Hisse başına kazanç tutarını kamuoyuna açıklayan bir işletme, söz konusu tutarı bu Standarda göre hesaplar ve kamuoyuna açıklar" (TMS 33, Madde 3)
} 
kurumsal yönetim ilkelerinden seffaflıkla ilişkisini görebiliriz.

\subsection{TMS 34: Ara Dönem Finansal Raporlama}

TMS 34 ara dönem finansal raporlama ile ilgili 45 standarttan oluşmaktadır. TMS 34 Amaç ${ }^{1}$ kısmında da belirtildiği üzere kurumsal yönetim ilkelerinden seffaflıktan bahsetmektedir. Çünkü bu anlatım ara dönem finansal raporlarda açık anlaşılır ve işletmeyle ilgili bir dönemi topluma yansıtması gerektiği söylenmektedir.

Ayrıca finansal raporlama işlemi kurumsal yönetim ilkelerinden hesap verilebilirlikle ilgilidir. Çünkü bu raporlar şirketin yönetimi tarafından hazırlanılmış olup şirket sahiplerine bu konuda hesap vermeleri gerekmektedir.

\subsection{TMS 36: Varlıklarda Değer Düşüklüğü}

TMS 36 varlıklarda değer düşüklüğü ile ilgili 140 madde ve ekten oluşan standarttır. TMS 36 incelendiğinde madde $1,6,7 \mathrm{~d}, 73,85,126,128$, $129,131,132,133,134,135$ ve 136 da değer

\footnotetext{
1 "Bu Standardın amacl; ara dönem finansal raporlamanın asgari içeriğinin tanımlanması ve ara döneme ilişkin özet veya ayrıntılı finansal tablolardaki muhasebeleştirme ve ölçme ilkelerini belirlemektir. Zamanında yapılan ve güvenilir bir ara dönem raporlama; yatırımcıların, kredi veren kuruluşların ve diğer tarafların işletmenin gelir ve nakit akışı yaratma "(TMS 34, Amaç)

2 "Paragraf 126-133 arasındaki bölüm, varlıklar ve nakit yaratan birimlere ilişkin değer düşüklüğü zararları ile değer düşüklüğü zararlarının iptaline ilişkin olarak kamuoyuna açıklanması gereken bilgileri belirler. Paragraf 134-137 arasındaki bölüm, değer düşüklüğü testi çerçevesinde kendilerine şerefiye veya sınırsız yararlı ömre sahip maddi olmayan duran varlık tahsis edilmiş bulunan nakit yaratan birimlere ilişkin olarak kamuoyuna yapılması gereken ilave açıklamaları gösterir" (TMS 36, Madde 7d)

3 "TFRS 3'e göre, bir işletme birleşmesinde muhasebeleştirilen şerefiye, işletme birleşmesi neticesinde ana ortaklık tarafından kontrol edilen şerefiye tutarından ziyade ana ortaklığın payı çerçevesinde elde ettiği şerefiyeyi gösterir. Bu nedenle, azınlık payına ait şerefiye ana ortaklığın konsolide finansal tablolarında muhasebeleştirilmez. Dolayısıyla, şerefiyenin dağıtıldığı nakit yaratan birimde bir azınlık payının bulunması durumunda, söz konusu birimin defter değeri şunlardan oluşur: (a) Anılan birimin belirlenebilir net varlıklarındaki
}

düşüklüğü ile ilgili bilgilerin kamuoyuna açıklanmasından bahsetmektedir.

Örneğin; TMS 36, Madde $7 \mathrm{~d}^{2}$ değer düşüklüğüne tabi para birimlerinin değer düşüklüklerinin kamuya açıklanmasından bahsetmektedir. $\mathrm{Bu}$ maddenin anlatımı kurumsal yönetim ilkelerinden seffaflıkla ilgisini kanıtlamaktadır.

Ayrıca, TMS 34, Madde 91'de ${ }^{3}$ paylar arasındaki eşitlikten bahsettiği için adillik ilkesiyle ilisşkisi de saptanmıştır.

\subsection{TMS 37: Karşılıklar, Koşullu Borçlar ve Koşullu Varlıklar}

TMS 37 karşılıklar, koşullu borçlar ve koşullu varlıklar ile ilgili 94 maddelik standarttır. TMS 37 incelendiğinde madde 20,73 ve 93 sseffaflık ilkesiyle ilișkisi saptanmıştır. Örneğin TMS 37 Madde $93^{4}$ kamuya açıklanması gereken bilgilerden bahsetmektedir ve bu açıkça seffaflık ilkesini göstermektedir.

Ayrıca, TMS 37, Madde $76^{5}$ yönetim kurulunun sorumluluğundan bahsettiği için kurumsal

ana ortaklığın ve de azınlığın payı; ile (b) Ana ortaklığın şerefiyedeki payı. Ancak, nakit yaratan birimin bu Standarda göre tespit edilen geri kazanılabilir tutarının bir kısmı, şerefiyedeki azınlık payına aittir" (TMS 34, Madde 91)

4 "Bu Standardı yürürlük tarihinde (veya daha öncesinde) uygulamanın etkisi, Standardın ilk uygulandığı dönem dağıtılmamış karlar açılış bakiyesine yapılmış bir düzeltme olarak raporlanır. İşletmeler, kamuya açıklanacak en erken dönem dağıtılmamış karlar açılış bakiyesini ve karşılaştırmalı bilgiyi düzeltme konusunda teşvik edilir, ancak bu düzeltmeler zorunlu değildir. Karşılaştırmalı bilginin düzeltilmemesi durumunda, anılan durum dipnotlarda açıklanır" (TMS 37, Madde 93)

5 "Zımni kabulden doğan bir yükümlülük, yalnızca yönetimin kararı sonucunda oluşmamış olsa bile, önceden oluşmuş olayların ilgili yönetimin kararı ile bir araya gelmeleri sonucunda bir yükümlülük oluşmuş olabilir. Örneğin; iş akitlerinin feshi ile ilgili olarak çalışan temsilcileriyle veya faaliyetin satışıyla ilgili olarak alıcılarla yapılan müzakereler, sadece yönetim kurulunun onayı çerçevesinde sonuçlanabilir. Bu onay bir kez alındıktan ve diğer taraflara bildirildikten sonra, Paragraf 72'de yer alan şartlara uyulması koşuluyla ilgili işletmenin yeniden yapılandırmaya ilişkin zımni kabulden doğan bir yükümlülüğü oluşur" (TMS 37, Madde 76) 
yönetim ilkelerinden sorumluluk ilkesiyle de ilişkili olduğunu göstermektedir.

\subsection{TMS 38: Maddi Olmayan Duran Varlıklar}

TMS 38 maddi olmayan duran varlıklarla ilgili 132 maddeden oluşan standarttır. TMS 38 incelendiğinde madde $118,120,121,124$ ve 128 kamuya açıklanması gereken bilgilerden bahsetmektedir. Örneğin; TMS 38, Madde $124^{1}$ araștırma ve geliștirme giderlerinin kamuya açıklanması gerektiğini belirttiğinden bu standardın seffaflık ilkesiyle ilişkisi olduğu söylenebilir.

\subsection{TMS 39: Finansal Araçlar: Muhasebeleştirme ve ölçme}

TMS 39 finansal araçlar ile ilgili 108 madde ve ekten oluşan standarttır. TMS 39 incelendiğinde madde 1, 9b, 45, 103, 103B, 104, $105 \mathrm{~b}$ ve $105 \mathrm{~d}$ kamuya açıklanması gereken bilgilerden bahsetmiștir. Böylece kurumsal yönetim ilkelerinden şeffaflık ile ilişkili olduğu görülmektedir.

Örneğin TMS 39 Madde $104^{2}$ yeniden ifade edilmenin uygun olmasının kamuya açıklanması gerektiğini ifade ettiğinden burada da seffaflık ilkesinin etkili olduğunu söyleyebiliriz.

\subsection{TMS 40: Yatırım Amaçlı Gayrimenkuller}

TMS 40 yatırım amaçlı gayrimenkuller ile ilgili 84 maddelik standarttır. TMS 40 incelendiğinde madde $3 f, 14,59,74,75,76,77,78,79$, 80a ve 80b maddeleri kamuoyuna açıklanması gereken bilgilerden bahsetmektedir. $\mathrm{Bu}$ da

\footnotetext{
1 "Işletme, dönem içinde gider olarak muhasebeleştirilen araştırma ve geliştirme harcamalarının toplam tutarını kamuoyuna açıklar" (TMS 38, Madde 124)

2 "Yeniden ifade edilme işleminin uygulanabilir olmaması durumunda, işletme, anılan durumu kamuoyuna açıklar ve ilgili bilginin ne kadarının yeniden ifade edildiğini gösterir" (TMS 39, Madde 104)

${ }^{3}$ Bu standardın 75 (c) Paragrafı, sınıflandırma işleminin güç olduğu durumlarda, söz konusu kriterlerin işletme
}

kurumsal yönetim ilkelerinden seffaflıkla ilgilidir.

Örnek vermek gerekirse; TMS 40 Madde $14^{3}$ sinıflandırmanın güç olduğu durumlarda bu durumun kamuya açıklanması gerektiğini belirttiğinden bu maddenin de şeffaflığın göstergesi olduğunu söylemek mümkündür.

\subsection{TMS 41: Tarımsal Faaliyetler}

TMS 41 tarımsal faaliyetlerle ilgili 59 maddeden oluşan standarttır. TMS 41 incelendiğinde kurumsal yönetim ilkelerinden herhangi biriyle ilişkisi saptanamamıștır

\section{KURUMSAL YÖNETIM ILKELERININ TÜRKIYE FINANSAL RAPORLAMA STANDARTLARI İÇINDEKI YERİ}

$\mathrm{Bu}$ başlık altında kurumsal yönetim ilkelerinin TFRS içindeki yeri analiz edilecek olup her bir standart tek tek incelenecektir.

\subsection{TFRS 1: Türkiye Finansal Raporlama Standardı}

TFRS 1, Türkiye Finansal Raporlama ile ilgili 46 madde ve eklerden oluşan standarttır. TFRS 1 incelendiğinde; madde 20A, 25B, 35, 36A, 37, $38,39,42$ ve 43 kamuya açlklanması gereken bilgilerden bahsettiği için kurumsal yönetim ilkelerinden şeffaflıkla ilişkilidir. Örnek verilecek olunursa TFRS 1 Madde $43{ }^{4}$ geçmiş dönemlerdeki finansal tabloların sunulmaması durumunun dahi kamuya açılanması gerektiğini belirttiğinden bu maddenin de seffaflık ilkesinin varlığına kanıt olduğunu söylemek mümkündür. Ayrıca TFRS 1 Ek B3 ${ }^{5}$ maddesi de yaplacak her hangi bir muafiyetin diğer paydaşlara ve ortaklıklara da uygulanması gerektiğini belirttiğinden kurumsal yönetim ilkelerinden adillik

tarafından kamuoyuna açıklanmasını gerektirir" (TMS 40, Madde 14)

4"Bir işletmenin geçmiş dönemlerin finansal tablolarını sunmamış olması durumunda, TFRS Standartlarına göre ilk kez düzenlenen finansal tablolarında bu husus kamuoyuna açıklanır"(TFRS 1, Madde 43)

5 "Geçmişteki şirket birleşmeleri için geçerli olan muafiyet ayrıca, geçmişteki bağlı ortaklık yatırımları, iş ortaklıkları için de geçerlidir. Ayrıca, Paragraf B1 için seçilen tarih her çeşit elde etme için geçerlidir" (TFRS 1, Ek B3) 
İzmir İktisat Dergisi (İzmir Journal of Economics) , Yll: 2019, Cilt:34, Sayı:4, ss. 527-543

ilkesinin TFRS 1'de geçerli olduğunu göstermektedir.

Ayrica finansal raporlama standartlarına uyma zorunluluğu olan işletme yönetim kurulları finansal tablo hazırladıkları için kurumsal yönetim ilkelerinden sorumluluk ve hesap verilebilirlik ilkesiyle de ilişkisini göstermektedir.

\subsection{TFRS 2:Hisse Bazlı Ödemeler}

TFRS 2, hisse bazlı ödemeler 64 madde ve ekten oluşan standarttır. TFRS 2 incelendiğinde; madde $44,45,46,47,48,49,50,51,52,54$ ve 58 kamuya açılanması gereken bilgilerden bahsetmektedir. Örneğin TFRS 244. maddesinden ${ }^{1}$ de anlaşılacağı üzere finansal bilgilerin kamu ile paylaşılması söz konusu olduğu için seffaflık ilkesiyle ilişkisi saptanmıştır.

\subsection{TFRS 3: İşletme Birleşmeleri}

TFRS 3, işletme birleşmeleri ile ilgili 85 madde ve ekten oluşan standarttır. TFRS 3 Madde $64^{2}$ incelendiğinde; bu madde ilgili hesaplardaki düzeltilmesi gereken muhasebe hesaplarının sanki hiç düzeltilmemiş gibi yansıtılması gerektiğini belirtmektedir. Bu durum aslında yine yapılan işlemlerin kamuoyuyla paylaşılmasını belirttiğinden bu standardın kurumsal yönetim ilkelerinden seffaflık ilkesiyle ilişkisini göstermektedir.

\footnotetext{
1 "Bir işletme finansal tablo kullanıcılarının, dönem boyunca var olan hisse bazlı ödeme anlaşmalarının nitelik ve tutarlarını anlamaları için gerekli bilgiyi kamuoyuna açıklar" (TFRS 2, Madde 44)

2 "TMS 8'e göre işletmeler hata düzeltmelerini geriye dönük olarak yapmak zorundadır ve finansal tabloların karşılaştırmalı bilgilerini hatanın olduğu dönem veya dönemlerde düzelterek sanki hiç hata olmamış gibi sunmalıdır. Bundan dolayı, edinen tarafın tanımlanabilir varlık, yükümlülük ve koşullu yükümlülüğünün hata neticesinde kayıtlara alınan veya düzeltilen kayıtlı değerinin hesaplamasında alım tarihindeki gerçeğe uygun değer veya düzeltilmiş gerçeğe uygun değer o tarihten itibaren muhasebeleştirilmiş gibi dikkate alınır. Şerefiye veya Paragraf 56'ya göre geçmiş dönemde muhasebeleştirilen herhangi bir gelir geriye dönük olarak muhasebeleştirilen tanımlanabilir varlık, yükümlülük ve koşullu yükümlülüğün
}

\subsection{TFRS 4: Sigorta Sözleşmeleri}

TRFS 4, sigorta sözleșmeleri ile ilgili 45 maddelik standarttır. TFRS 4 incelendiğinde; madde $36,37,38$ ve 39 da kamuoyu ile paylaşılması gereken bilgilerden bahsettiği için kurumsal yönetim ilkelerinden seffaflıkla iliskisi vardır. Örneğin TFRS 4 Madde 38'den ${ }^{3}$ de anlaşılacağı üzere sigorta sözleşmelerinden doğan risklerin kamuoyuyla paylaşılması kurumsal yönetim ilkelerinden şeffaflık ilkesi ile ilişkili olabilmektedir.

\subsection{TFRS 5: Satış Amaçlı Elde Tutulan Duran Varlıklar ve Durdurulan Faaliyetler}

TFRS 5, satış amaçlı elde tutulan duran varlıklar ve durdurulan faaliyetlerle ilgili 43 madde ve ekten oluşan standarttır. TFRS 5 incelendiğinde; madde 30,33 ve 34 kamuoyuna açıklanması gereken bilgilerden bahsetmektedir. Örneğin TFRS 5 Madde $30^{4}$ da duran varlıkların elden çıkarılmasına ilişkin yapılan işlemlerin kamuoyuyla paylaşılması gerektiği söylenmiștir. Bu durum kurumsal yönetim ilkelerinden seffaflık ilkesi ile ilișkisi olduğunu göstermektedir.

\subsection{TFRS 6: Maden Kaynaklarının Araştırılması ve Değerlendirilmesi}

TFRS 6 maden kaynaklarının araștırılması ve değerlendirilmesi ile ilgili 27 madde ve ekten oluşan standarttır. TFRS 6 , Madde $18^{5}$

birleşeme tarihindeki gerçeğe uygun değerine eşit tutarda düzeltilmelidir" (TFRS 3, Madde 64)

3 "Sigortacı, finansal tablo kullanıcılarının, sigorta sözleşmelerinden doğan riskin yapısı ve boyutunu anlamasına yardımcı olacak bilgileri kamuoyuna açıklar" (TFRS 4, Madde 38)

4 "Işletme, duran varlıkların (veya elden çıkarılacak varlık gruplarının) elden çıkarılmasının veya durdurulan faaliyetlerin finansal etkilerini finansal tablo kullanıcılarının değerlendirebilmelerini sağlayacak bilgiyi sunar ve kamuoyuna açıklar" (TFRS 5, Madde 30)

5 "Bilgiler ve koşullar, araştırma ve değerlendirme varlığının defter değerinin geri kazanılabilir tutarını aşabileceğini gösterdiğinde araştırma ve değerlendirme varlıkları değer düşüklüğü açısından değerlendirilir. Bilgiler ve koşullar, defter değerinin geri kazanılabilir tutarı aştığını gösterdiğinde bir işletme, aşağıda paragraf 21 'de belirtilen 
incelendiğinde; yine değer düşüklüklerinin de ölçülmesinde ve değerlendirilmesinde yapılan işlemlerin kamuoyuyla paylaşılması gerektiğini belirtmiştir. $\mathrm{Bu}$ standardında bu maddeden yola çıkarak kurumsal yönetim ilkelerinden seffaflık ilkesi ile ilişkisini ortaya koyabiliriz.

\subsection{TFRS 7: Finansal Araçlar: Açıklamalar}

TFRS 7 Finansal Araçlar: Açılklamalara İlişkin 45 maddelik standarttır. TFRS 7 incelendiğinde; madde $1,6,7,8,9,10,11,14$, $15,16,17,19,20,22,25,26,31,33,34,36,37$, 42, Ek B3, B4, B5, B7, B9, B11C, B11E, B17, B18, B24, B25, B26 ve B27 maddeleri kamuoyuna açıklanması gereken finansal bilgilerden bahsetmektedir. İlk maddeden de anlaşılacağı üzere finansal tablolarda işletmenin performansını ve maruz kalabileceği risklerin görülebilecek düzeyde kamuoyuyla paylaşılmasını belirtmektedir (TFRS 7, Madde 1) ${ }^{1}$. Bu amaçla bu standardın da kurumsal yönetim ilkelerinden seffaflık ilkesiyle ilişkili olduğunu söyleyebiliriz.

\subsection{TFRS 8: Faaliyet Bölümleri}

TFRS 8 faaliyet bölümleri ile ilgili 36 madde ve ekten oluşan standarttır. TFRS 8 Madde 42 incelendiğinde; bu madde belli durumlar gerçekleştiğinde konsolide finansal tablolarda sadece bölümlere ilişikin bilgilerin açıklanması gerektiğini söylemektedir. $\mathrm{Bu}$ finansal tabloların kamuoyuyla paylaşılması gerektiğinden bu standardında kurumsal

istisna hariç olmak üzere, oluşan değer düşüklüğü zararını TMS 36 uyarınca ölçer, sunar ve kamuya açıklar" ( TFRS 6, Madde 18)

1 “Bu TFRS'nin amacı, finansal tablo kullanıcılarının şu hususları değerlendirebilmeleri için gerekli olan bilgilerin işletme finansal tablolarında kamuoyuna açıklanmasını sağlamaktır: (a) Finansal araçların işletmenin finansal durumu ve performansı açısından önemi ve (b) işletmenin dönem içerisinde ve raporlama dönemi sonunda finansal araçlar nedeni ile maruz kaldığı risklerin niteliği ve düzeyi ile işletmenin sözü edilen riskleri yönetme şekli" (TFRS 7, Madde 1)

2"Bir finansal raporun, bir ana ortaklığın bu TFRS kapsamında olan konsolide finansal tablolarına ek olarak bu ana ortaklığın bireysel finansal tablolarını da içermesi yönetim ilkelerinden șeffaflıkla ilișkisi olduğu saptanmıștır.

\subsection{TFRS 9: Finansal Araçlar:}

TFRS 9 finansal araçlar 7 madde ve ekten oluşan standarttır. TFRS 9 Madde $4.2 .2^{3}$ incelendiğinde; işletmelerin finansal yükümlülüklerin ve finansal varlıklarında oluşabilecek riskler ve bunların giderilmesine ilişkin stratejiler yönetim kuruluna sunulması gerektiğini belirttiğinden bu standardın kurumsal yönetim ilkelerinden adillik ilkesiyle ilişkili olduğu anlaşılmaktadır.

\subsection{TFRS 10: Konsolide Finansal Tablolar}

TFRS 10 konsolide finansal tablolar ile ilgili 32 madde ve ekten oluşan standarttır. TFRS 10 incelendiğinde; madde 4 ii, iii, iv kamuya açıklık durumundan bahsettiği için kurumsal yönetim ilkelerinden seffaflıkla ilgili olduğu anlaşılmaktadır. Ayrıntıya baktığımızda TFRS 10, Madde 4 iv $^{4}$ de ana ortaklığın kamuya açıkladığı gerçeğe uygun finansal raporlarına paralel olarak bağlı ortaklıklarında gerçeğe uygun hazırlaması gerektiğini belirtmiştir. $\mathrm{Bu}$ açıklamada yorumumuzu kanıtlamaktadır.

Ayrica konsolide finansal tabloların hazırlanması yönetimin görevi olduğu için hesap verilebilirlikle ilişkisini göstermektedir. $\mathrm{Bu}$ tabloların hazırlanmasından işletme sahiplerine karşı hesap verme zorunluluğu gerektirmektedir.

durumunda; bölümlere ilişkin bilgi sadece konsolide finansal tablolarda açıklanır"(TFRS 8, Madde 4)

3 "Bir finansal yükümlülük grubu veya finansal varlık ve finansal yükümlülükleri içeren bir grup, belgelendirilmiş bir risk yönetimi veya yatırım stratejisi çerçevesinde gerçeğe uygun değer esas alınarak yönetilmekte ve performansları buna göre değerlendirilmektedir. Ayrıca işletmenin kilit yönetici personeline örneğin yönetim kuruluna ve icra kurulu başkanına, ilgili grup hakkında bu esasa göre bilgi sunulmaktadır" (TFRS 9, Madde 4.2.2)

4 "Ana ortaklık veya ara kademe bir ana ortaklığın kamunun kullanımına açık ve bu TFRS uyarınca gerçeğe uygun değer farkı kâr veya zarara yansıtılarak ölçülen veya konsolide edilen bağlı ortaklıklarının TFRS'lere uygun finansal tablolar hazırlıyor olması" (TFRS 10, Madde 4 iv) 


\subsection{TFRS 11: Müşterek Anlaşmalar}

TFRS 11 müşterek anlaşmalar ile ilgili 27 madde ve ekten oluşan standarttır. TFRS 11, Ek B17 ${ }^{1}$ incelendiğinde; müşterek anlaşmalarda hasılat ve giderlerin ne şekilde paylaşılması gerektiği finansal tablolarda açıklanması gerektiği belirttiğinden bu standardın kurumsal yönetim ilkelerinden seffaflıkla ilişkisi olduğu anlaşılmaktadır. Çünkü işletmeyle ilgili durumun finansal tablolara yansıtılmasından bahsedilmiştir.

\subsection{TFRS 12: Diğer İşletmelerdeki Paylara İlişkin Açıklamalar}

TFRS 12 Diğer İşletmelerdeki Paylara İlişkin Açılklamalar standardı 31 madde ve eklerden oluşmaktadır. TFRS 12 incelendiğinde; ilgili standardın diğer tüm standartlarla bağlantılı bir şekilde raporlamaların yapılması gerektiği açıklanmıştır. Yapılan bu yorum sonucunda aslında ilgili standardın kurumsal yönetim ilkelerinin tümüyle bağlantılı olduğu standardın her bir maddesi ayrı ayrı incelendiğinde anlaşılmaktadır. Bu bağlamda bu standardın kurumsal yönetim ilkeleri olan seffaflık, hesap verebilirlik, adillik ve sorumluluk ilkesi ile ilişkili olduğu söylenebilir.

\subsection{TRFS 13: Gerçeğe Uygun Değer Ölçümü}

TFRS 13 gerçeğe uygun değer ölçümü ile ilgili 99 madde ve ekten oluşan standarttır. TFRS 13

\footnotetext{
1 "Sözleşmeye bağlı anlaşma, çoğu kez anlaşmanın konusunu oluşturan faaliyetlerin niteliğini ve tarafların söz konusu faaliyetleri üstlenmeyi ne şekilde tasarladıklarını tanımlamaktadır. Örneğin; müşterek anlaşmanın tarafları, her bir tarafın belirli bir görevden sorumlu olduğu ve ayrıca her birinin kendi varlıklarını kullanıp kendi adına borçlandığı bir yapı içerisinde birlikte ürün imal etmek konusunda anlaşabilir. Ayrıca sözleşmeye bağlı anlaşma, taraflar arasında ortak olan hasılat ve giderlerin söz konusu taraflar arasında ne şekilde paylaştırılacağını da belirleyebilir. Böyle bir durumda, her bir müşterek faaliyet katılımcısı belirli görev için kullanılan varlık ve borçları kendi finansal tablolarına yansıtır ve hasılat ile giderlere ilişkin payını sözleşmeye bağlı anlaşma uyarınca muhasebeleştirir " (TFRS 11, Ek B17)

2 "Sınırlı bilginin kamunun erişimine açık olması (aracısız bir piyasada meydana gelen işlemler gibi)" (TFRS13, Ek B37)
}

Ek B372 incelendiğinde; bu madde gerçeğe uygun değerlerin ölçülmesinde sınırlı olan bilgilerin kamuya açıklanmasıyla ilgili olduğundan standardın kurumsal yönetim ilkelerinden seffaflıkla ilgisi olduğu anlașılmaktadır.

Ayrıca TFRS 13, Madde $49^{3}$ incelendiğinde; bu madde işletmelerin faaliyetleri sonucunda raporlarında belirttiği finansal varlıklar ve borçlardan dolayı kilit yöneticilere bilgi sunması gerektiğini belirttiğinden standardın adillik ilkesiyle de ilişkili olduğunu söyleyebiliriz.

\subsection{TFRS 14: Düzenlemeye Dayalı Erteleme Hesapları}

TFRS 14 düzenlemeye dayalı erteleme hesapları ile ilgili 36 madde ve ekten oluşan standarttır. TFRS 14 Madde $27^{4}$ incelendiğinde; bu maddede işletmenin sunduğu mal ve hizmet karşıllığında müşterilerden talep ettiği fiyatın fiyat tarifesi ile ilgili olup olmadığını bu tarifenin olası etkilerinin finansal tablo kullanıcılarına açıklanması gerektiğini belirtmektedir. $\mathrm{Bu}$ standardın kurumsal yönetim ilkelerinden seffaflıkla ilișkisi vardır diyebiliriz.

Ayrıca TFRS 14 B145 maddesi incelendiğinde hisse başına kazançların nasıl sunulması gerektiğini ve bu sunumun hisse başına

\footnotetext{
3 "İşletmenin kilit yöneticilerine (TMS 24 ilişkili Taraf Açıklamaları Standardında tanımlandığı şekliyle) finansal varlıklar ve borçlardan oluşan grup hakkında (a) bendinde belirtilen esasa göre bilgi sunulması" (TFRS 13, Madde 49)

4 "Bu Standardı uygulamayı seçen bir işletme, finansal tablo kullanıcılarının aşağıdaki hususları değerlendirebilmesine imkân sağlayan bilgileri açıklar: (a) iş̧letmenin sunduğu mal veya hizmetler karşılığında müşterilerden talep edebildiği fiyatı (veya fiyatları) belirleyen tarife düzenlemesinin yapısını ve tarife düzenlemesiyle ilişkili riskleri ve (b) $\mathrm{Bu}$ tarife düzenlemesinin işletmenin finansal durumu, finansal performansı ve nakit akışları üzerindeki etkileri" (TFRS 14, Madde 27)

5 "Bu Standardı uygulayan bir işletme, TMS 33'e göre sunulan her bir pay başına kazanç tutarı için, düzenlemeye dayalı erteleme hesap bakiyelerinde meydana gelen net değişimlerin dâhil edilmemesi dışında aynı şekilde hesaplanan ilave adi ve seyreltilmiş pay başına kazançları
} 
kazançlara eșit derecede önem verecek șekilde yapılması gerektiğini belirttiğinden kurumsal yönetim ilkelerinin adillik ilkesiyle ilişkisi olduğunu kanıtlamaktadır.

\subsection{TFRS 15: Müşteri Sözleşmelerinde Hasılat}

TFRS 15 müşteri sözleşmelerinde Hasılat ile ilgili 129 madde ve ekten oluşan standarttır. TFRS 15 incelendiğinde madde $8,110,113,115$, $116,117,119,120,122,123,124,125,126,128$ ve 129 işletmenin açıklaması gereken bilgilerden bahsettiği için kurumsal yönetim ilkelerinden şeffaflıkla ilgisini göstermektedir.

\section{KURUMSAL YÖNETIM İLKELERİNIN TMS VE TFRS İÇİNDEKİ YERİNÍN ANALİZI}

Yukarıda incelenen 30 ayrı TMS ve 15 ayrı TFRS'ler sonucunda aşağıdaki gibi bir tablo ortaya çlkmıştır. Bu tabloda 7 adet TMS standardında kurumsal yönetim ilkeleri tespit edilememiş ancak diğer standartlarda bu ilkeler tespit edilebilmiştir. Aynı zamanda incelenen TFRS'lerin tamamında kurumsal yönetim ilkelerine rastlanmıștır. Aşağıdaki tabloda TMS ve TFRS'ler ayrı ayrı incelenmiş olup kurumsal yönetim ilkeleri ile bağlantılı olan standartlar belirtilmiştir.

Tablo 1. Kurumsal yönetim ilkelerinin TMS Ve TFRS içindeki yerinin analizi

\begin{tabular}{|c|c|c|c|c|}
\hline $\begin{array}{l}\text { TÜRKIYY MUHASEBE } \\
\text { İLKELERİ İLE OLAN BA }\end{array}$ & $\begin{array}{l}\text { ANDAR' } \\
\text { ANTISI }\end{array}$ & RININ K & RUMS & ÖNETIM \\
\hline STANDARTLAR & KUR & MSAL YÖN & ETIMM İLKI & LERİ \\
\hline & Adillik & Şeffaflık & $\begin{array}{c}\text { Sorumlu } \\
\text { luk }\end{array}$ & $\begin{array}{c}\text { Hesap } \\
\text { verilebili } \\
\text { rlik }\end{array}$ \\
\hline $\begin{array}{l}\text { TMS 1: Finansal } \\
\text { Tabloların Sunuluşu }\end{array}$ & & VAR & & VAR \\
\hline TMS 2: Stoklar & BAĞL $f$ & ITI TESPİT & EDİLEME & MİȘTİR \\
\hline $\begin{array}{l}\text { TMS 7: Nakit Akış } \\
\text { Tabloları: }\end{array}$ & & VAR & & \\
\hline $\begin{array}{l}\text { TMS 8: Muhasebe } \\
\text { Politikaları, Muhasebe } \\
\text { tahminlerinde } \\
\text { Değişiklikler Ve } \\
\text { Hatalar }\end{array}$ & & VAR & & \\
\hline $\begin{array}{l}\text { TMS 10: Bilanço } \\
\text { Tarihinden Sonraki } \\
\text { Olaylar }\end{array}$ & & VAR & & \\
\hline $\begin{array}{l}\text { TMS 11: İnşaat } \\
\text { Sözlesmeleri }\end{array}$ & & IES & EDİLEN & MISSTIIR \\
\hline
\end{tabular}

sunar. İşletme TMS 33'ün 73 üncü paragrafına uygun şekilde, bu Standardın 26 ncı paragrafında zorunlu kılınan pay başına kazançları, sunumu yapılan tüm dönemlerde

\begin{tabular}{|c|c|c|c|c|}
\hline $\begin{array}{l}\text { TMS 12: Gelir } \\
\text { Vergileri }\end{array}$ & VAR & VAR & & \\
\hline $\begin{array}{l}\text { TMS 14: Bölümlere } \\
\text { Göre Raporlama }\end{array}$ & & VAR & VAR & \\
\hline $\begin{array}{l}\text { TMS 16: Maddi Duran } \\
\text { Varlıklar } \\
\end{array}$ & \multicolumn{4}{|c|}{ BAĞLANTI TESPİT EDİLEMEMIŞTİR } \\
\hline $\begin{array}{l}\text { TMS 17: Kiralama } \\
\text { İșlemleri }\end{array}$ & \multicolumn{4}{|c|}{ BAĞLANTI TESPİT EDİLEMEMIŞTİR } \\
\hline TMS 18: Hasılat & \multicolumn{4}{|c|}{ BAĞLANTI TESPİT EDILEMEMIȘTIR } \\
\hline $\begin{array}{l}\text { TMS 19: Çalışanlara } \\
\text { Sağlanan Faydalar }\end{array}$ & VAR & VAR & & \\
\hline $\begin{array}{l}\text { TMS 20: Devlet } \\
\text { Teşviklerinin } \\
\text { Muhasebeleştirilmesi } \\
\text { ve Devlet } \\
\text { Yardımlarının } \\
\text { Açıklanması }\end{array}$ & & & & VAR \\
\hline $\begin{array}{l}\text { TMS } 21 \text { Kur } \\
\text { Değișiminin Etkileri }\end{array}$ & & VAR & & \\
\hline $\begin{array}{l}\text { TMS 23: Borçlanma } \\
\text { Maliyetleri }\end{array}$ & & VAR & & \\
\hline $\begin{array}{l}\text { TMS 24: İliş̧ili Taraf } \\
\text { Açıklamaları }\end{array}$ & & VAR & & \\
\hline $\begin{array}{l}\text { TMS 26: Emeklilik } \\
\text { Fayda Planlarında } \\
\text { Muhasebeleştirme ve } \\
\text { Raporlama }\end{array}$ & & VAR & & \\
\hline $\begin{array}{l}\text { TMS 27: Konsolide ve } \\
\text { Bireysel Finansal } \\
\text { Tablolar }\end{array}$ & VAR & VAR & & VAR \\
\hline $\begin{array}{l}\text { TMS 28: İştiraklerde } \\
\text { Yatırım }\end{array}$ & VAR & VAR & & \\
\hline $\begin{array}{l}\text { TMS 29: Yüksek } \\
\text { Enflasyonlu } \\
\text { Ekonomilerde } \\
\text { Finansal Raporlama } \\
\end{array}$ & \multicolumn{4}{|c|}{ BAĞLANTI TESPİT EDÍLEMEMIŞTIR } \\
\hline $\begin{array}{l}\text { TMS 31: İş } \\
\text { Ortaklıklarındaki } \\
\text { Paylar }\end{array}$ & VAR & & & \\
\hline $\begin{array}{l}\text { TMS 32: Finansal } \\
\text { Araçlar: Sunum }\end{array}$ & & VAR & & \\
\hline $\begin{array}{l}\text { TMS 33: Hisse Başına } \\
\text { Kazanç }\end{array}$ & & VAR & & \\
\hline $\begin{array}{l}\text { TMS 34: Ara Dönem } \\
\text { Finansal Raporlama }\end{array}$ & & VAR & & VAR \\
\hline $\begin{array}{l}\text { TMS 36: Varlıklarda } \\
\text { Değer Düşüklüğü }\end{array}$ & VAR & VAR & & \\
\hline $\begin{array}{l}\text { TMS 37: Karşılıklar, } \\
\text { Koşullu Borçlar ve } \\
\text { Koşullu Varlıklar }\end{array}$ & & VAR & VAR & \\
\hline $\begin{array}{l}\text { TMS 38: Maddi } \\
\text { Olmayan Duran } \\
\text { Varlıklar }\end{array}$ & & VAR & & \\
\hline $\begin{array}{l}\text { TMS 39: Fin. Araçlar: } \\
\text { Muhasebeleştirme ve } \\
\text { Ölçme }\end{array}$ & & VAR & & \\
\hline $\begin{array}{l}\text { TMS 40: Yat. Amaçlı } \\
\text { Gayrimenkuller }\end{array}$ & & VAR & & \\
\hline $\begin{array}{l}\text { TMS 41: Tarımsal } \\
\text { Faaliyetler }\end{array}$ & BAĞL & NTI TESPII & T EDİLEMEI & MişTír \\
\hline \multicolumn{5}{|c|}{ TÜRKIYE FINANSAL RAPORLAMA STANDARTLARININ ANALİ } \\
\hline \multirow[t]{2}{*}{ STANDARTLAR } & \multicolumn{4}{|c|}{ KURUMSAL YÖNETIMM İLKELERİ } \\
\hline & Adillik & Şeffaflık & $\begin{array}{c}\text { Sorumlu } \\
\text { luk }\end{array}$ & \begin{tabular}{|c|} 
Hesap \\
verilebil \\
rlik
\end{tabular} \\
\hline
\end{tabular}

bunlara TMS 33'de zorunlu kılınan pay başına kazançlarla eşit derecede önem vererek sunar" (TFRS 14, B14) 


\begin{tabular}{|c|c|c|c|c|}
\hline $\begin{array}{l}\text { TFRS 1: Türkiye } \\
\text { Finansal Raporlama } \\
\text { Standardi }\end{array}$ & VAR & VAR & & VAR \\
\hline $\begin{array}{l}\text { TFRS 2:Hisse Bazlı } \\
\text { Ödemeler }\end{array}$ & & VAR & & \\
\hline $\begin{array}{l}\text { TFRS 3: İşletme } \\
\text { Birleşmeleri }\end{array}$ & & VAR & & \\
\hline $\begin{array}{l}\text { TFRS 4: Sigorta } \\
\text { Sözleșmeleri }\end{array}$ & & VAR & & \\
\hline $\begin{array}{l}\text { TFRS 5: Satış Amaçlı } \\
\text { Elde Tutulan Duran } \\
\text { Varlıklar ve } \\
\text { Durdurulan } \\
\text { Faaliyetler }\end{array}$ & & VAR & & \\
\hline $\begin{array}{l}\text { TFRS 6: Maden } \\
\text { Kay.Araş. ve Değ. }\end{array}$ & & VAR & & \\
\hline $\begin{array}{l}\text { TFRS 7: Finansal } \\
\text { Araçlar: Açıklamalar }\end{array}$ & & VAR & & \\
\hline $\begin{array}{l}\text { TFRS 8: Faaliyet } \\
\text { Bölümleri }\end{array}$ & & VAR & & \\
\hline $\begin{array}{l}\text { TFRS 9: Finansal } \\
\text { Araçlar: }\end{array}$ & VAR & & & \\
\hline $\begin{array}{l}\text { TFRS 10: Konsolide } \\
\text { Finansal Tablolar }\end{array}$ & & VAR & & VAR \\
\hline $\begin{array}{l}\text { TFRS 11: Müşterek } \\
\text { Anlașmalar }\end{array}$ & & VAR & & \\
\hline $\begin{array}{l}\text { TFRS 12: Diğer İşl. } \\
\text { Pay. İlişkin } \\
\text { Açlklamalar }\end{array}$ & VAR & VAR & VAR & VAR \\
\hline $\begin{array}{l}\text { TRFS 13: Gerçeğe } \\
\text { Uygun Değer Ölçümü }\end{array}$ & VAR & VAR & & \\
\hline $\begin{array}{l}\text { TFRS 14: Düz. Dayalı } \\
\text { Erteleme Hesapları }\end{array}$ & VAR & VAR & & \\
\hline $\begin{array}{l}\text { TFRS 15: Müşteri } \\
\text { Sözleşmelerinde } \\
\text { Hasılat }\end{array}$ & & VAR & & \\
\hline
\end{tabular}

\section{SONUÇ}

TMS ve TFRS'de belirlenmiş olan standartlarımız oluşum amacına göre mutlaka kurumsal yönetim ilkelerini barındırması gerekmektedir. Yapılan inceleme sonucunda hangi kurumsal yönetim ilkesinin hangi standartla ilişkisi olduğu saptanmıştır. Buna göre kurumsal yönetim ilkelerinden şeffaflık ilkesinin standartların oluşumunda çok etkili olduğu, adillik ve hesap verilebilirlik ilkelerinin standartlarının oluşumunda sıklıkla etkili olduğu ve sorumluluk ilkesinin ise standartların oluşumunda en az etkiye sahip olduğu görülmüştür.

Ayrıca tablodan elde edilen verilere göre $\underline{\text { TMS }}$ için şu sonuçlara varılmıştır:

- $\quad$ Kurumsal yönetim ilkelerinden şeffaflık ilkesiyle ilişkili olan Türkiye Muhasebe Standart sayısı 21'dir.

- $\quad$ Kurumsal yönetim ilkelerinden adillik ilkesiyle ilişkili olan Türkiye Muhasebe Standart sayısı 6'dır.
- Kurumsal yönetim ilkelerinden sorumluluk ilkesiyle ilişkili olan Türkiye Muhasebe Standart sayısı 2'dir.

- Kurumsal yönetim ilklerinden hesap verilebilirlik ilkesiyle ilişkili olan Türkiye Muhasebe Standart sayısı 4'tür.

- Kurumsal yönetim ilkelerinden adillik ve şeffaflık ilkelerinin ikisiyle ilişkili olan Türkiye Muhasebe Standart sayısı 5 olup bunlar; TMS 12, TMS 19, TMS 27, TMS 28, TMS 36'dır.

- Kurumsal yönetim ilkelerinden adillik, şeffaflık ve hesap verilebilirlik ilkelerinden üçüyle ilişkili olan Türkiye Muhasebe Standart sayısı 1 olup bu; TMS 27'dir.

- $\quad$ Kurumsal yönetim ilkelerinden şeffaflık ve hesap verilebilirlik ilkelerinden ikisiyle ilişkili olan Türkiye Muhasebe Standart sayısı 2 olup bunlar; TMS 1 ve TMS 34 'tür.

- $\quad$ Kurumsal yönetim ilkelerinden şeffaflık ve sorumluluk ilkelerinden ikisiyle ilişkili olan Türkiye Muhasebe Standart sayısı 2 olup bunlar; TMS 14 ve TMS 37'dir.

- $\quad$ Kurumsal yönetim ilkelerinin dördüyle ilişkili olan Türkiye Muhasebe Standardı bulunmamıștır.

Bunun yanında tablodan elde edilen verilere göre TFRS için şu sonuçlara varılmıştır;

- $\quad$ Kurumsal yönetim ilkelerinden şeffaflık ilkesiyle ilişkili olan Türkiye Finansal Raporlama Standart sayısı 14'tür.

- $\quad$ Kurumsal yönetim ilkelerinden adillik ilkesiyle ilişkili olan Türkiye Finansal Raporlama Standart sayısı 4'tür.

- Kurumsal yönetim ilkelerinden sorumluluk ilkesiyle ilişkili olan Türkiye Finansal Raporlama Standart bulunmamıştır.

- Kurumsal yönetim ilkelerinden hesap verilebilirlik ilkesiyle ilişkili Türkiye Finansal Raporlama Standart sayısı 2'dir.

- $\quad$ Kurumsal yönetim ilkelerinden şeffaflık ve adillik ilkelerinden ikisiyle ilişkili olan Türkiye Finansal Raporlama Standart sayısı 2 olup bunlar; TFRS 13 ve TFRS 14'tür.

- Kurumsal yönetim ilkelerinden şeffaflık ve hesap verilebilirlik ilkelerinden ikisiyle 
ilișkili olan Türkiye Finansal Raporlama Standart sayısı 1 olup bu; TFRS 10'dur.

- Kurumsal yönetim ilkelerinden şeffaflık, hesap verilebilirlik ve adillik ilkelerinden üçüyle ilişkili olan Türkiye Finansal Raporlama Standart sayısı 1 olup bu; TFRS 1'dir.

- $\quad$ Kurumsal yönetim ilkelerinin dördüyle ilişkili olan Türkiye Finansal Raporlama Standardı 1 adettir olup bu; TFRS 12'dir.

Yukarıdaki analizler sonucunda TMS ve TFRS'nin oluşumunda kurumsal yönetim ilkelerinin etkisinin (özellikle şeffaflık ilkesinin) varlığı Türkiye'de oluşturulacak muhasebe sistemleri için olumlu olduğunu söyleyebiliriz. Özellikle küreselleşme etkisinde ki dünyada küreselleşmeye doğru evrilen firmaların mali tablolarının, bu tabloları kullananlar için şeffaf olması gerektiği noktasında önemlilik arz etmektedir.
İșletmeler kurumsallaștıkça firmaların mali tabloları da kurumsallaşıp kamuya mal olacaktır. $\mathrm{Bu}$ durumda kurumsal yönetim ilkelerinin etkisi burada kendisini gösterecektir. Çalışma bu etkinin analizine yönelik yapılmıştır. $\mathrm{Bu}$ çalışma sonucunda işletmelerin kurumsal yönetim ilkelerini içselleştirerek uygulama yapmaları gerektiği ve özellikle ülkemizde yeni olan TMS ve TFRS uygulamalarında daha etkin kullanılması gerektiği önerile bilinir. Bu amaçla kurumsal yönetim ilkeleri yöneticiler tarafından tüm çalışanlara ve özellikle muhasebe departmanında çalışan personele eğitimlerle anlatılması gerekmektedir. Aynı zamanda TMS ve TFRS eğitimlerinin verildiği özel ve kamu kurumlarında standartların kurumsal yönetim ilkeleri ile bağlantısı kurularak, paralel bir şekilde eğitimlerin verilmesi gerektiği ayrıca vurgulanmalıdır.

\section{REFERANSLAR}

Akyüz, Y., Görmüş, A.Ş., Bektaş, Ç., (2008). "Bilgi Toplumuna Geçiş sürecinde Bilginin Artan Ekonomik Değeri ve İşletmeler Üzerindeki Etkileri", s.1-10.

Atabey, N.A., Yılmaz, B., Ay, M., (2005). AB'ne Katılım Sürecinde Muhasebenin Sosyal Sorumluluk Kavramı Açısından Kurumsal Yönetim. IV Orta Anadolu İşletmecilik Kongresi, TOOB Ekonomi ve Teknoloji Üniversitesi, Ankara, s. 110.

Aysan, M., (2007). Kurumsal Yönetim ve Risk, İstanbul: Elit ofset, s.82.

Aysan, M., (2007). "Muhasebe ve Kurumsal Yönetim", İstanbul Üniversitesi Sosyal Bilimler Enstitüsü, s.20.

Clark,W,. Demirağ, İ., (2002). "Enron the failure of corparete governance ", JCC 8 Greenleaf Publishing.

Dinç, E., Abdioğlu, H., (2009). "İşletmelerde kurumsal Yönetim Anlayışı ve Muhasebe Bilgi Sistemi İlişkisi: İMKB-100 Şirketleri Üzerine Ampirik Bir Araştırma", Balıkesir Üniversitesi
Sosyal bilimler Enstitüsü Dergisi, Cilt: 12, s. 21, Haziran.

Ege, İ.. (2004). “KOBİlerde Kurumsal Yönetimin Finansal Açıdan Öneminin Sözlü Tarih Yöntemiyle Analizi, KOBI'lerin Halka Açılması ve SPK", Muğla.

Karğın, M., Aktaş, R., Demirel Arıcı, N., (2015). "Kurumsal Yönetimin Finansal Raporlama Kalitesindeki Rolü: Borsa İstanbul Üzerine Karşılaștırmalı Bir Uygulama", Celal Bayar Üniversitesi Sosyal Bilimler Enstitüsü, Cilt 22, s.2.

Koçel, T,. (2003). İşletme Yöneticiliği, İstanbul: Beta Basım Yayım Dağıtım A.Ş.

Menteş, A,. (2009). Kurumsal Yönetişim ve Türkiye Analizi, s.33,İstanbul: Derin Yayınları.

Millstein, M.. (1998). "Corparete governance Improving Competitiveness And Acces To Capital in Global Markets".

Şehirli, K,. (1999). Kurumsal Yönetim, Araştırma Raporu, Ankara: SPK Denetleme Dairesi. 
İzmir İktisat Dergisi (İzmir Journal of Economics) , Yıl: 2019, Cilt:34, Sayı:4, ss. 527-543

TÜSİAD (Türkiye Sanayici ve İş Adamları Derneği), (2002). Kurumsal Yönetim En İyi Uygulama Kodu: Yönetim Kurulunun Yapısı ve İşleyişi, Yayın No:336, İstanbul, Aralık.

Tuzcu, M.A., (2003). Halka Açık Şirketlerde Kurumsal Yönetim Anlayışı: İMKB-100 Örneği, Ankara Üniversitesi Sosyal Bilimler Enstitüsü, Ankara.

Uyar, S., (2004). "Kurumsal Şeffaflı̆ı̆ın Sağlanmasında Kurumsal Yönetim Anlayışını Önemi".

Ülzen, H.. Mirze, K., (2004). İşletmelerde Stratejik Yönetim, İstanbul: Literatür Yayınları.

Yılmaz, R., Kaya, M., (2014). "Kurumsal Yönetim İlkelerinin Muhasebe Etik Kuralları İle İlişkisi”.
Sakarya Üniversitesi Sosyal Bilimler Enstitüsü, İşletme Bilimi Dergisi, Cilt 2, s.1.

Uluslararası Ekonomi Ve İșletme Kongresi (ICEB'15) Bildiriler Kitabı, (2015) bu kaynağa (http://icebconference.org/2018/wpcontent/uploads/2018/01/ICEB-2015.pdf) internet adresinden ulaşılmıştır.

URL-1, 2019 www.kgk.gov.tr / Kamu Gözetimi Kurumu

URL-2, 2019 www.spk.gov.tr / Sermaye Piyasası Kurulu

URL-3, 2019www.pwc.com.tr / PwC Denetim Şirketi 